\title{
$\frac{17 y}{78}$ \\ (online) $=$ ISSN $2285-3642$ \\ ISSN-L = $2285-3642$ \\ Journal of Economic Development, Environment and People \\ Volume 9, Issue 4, 2020 \\ URL: http://jedep.spiruharet.ro \\ e-mail: office jedep@spiruharet.ro \\ Business Environment and Start-Up in Indonesia:Empirical Evidence from Province-level Data
}

\author{
Alghifari Mahdi Igamo ${ }^{1}$, Agung Putra Raneo ${ }^{2}$, Nur Khamisah ${ }^{3}$ and Arika Kurniawan ${ }^{4}$ \\ ${ }^{1}$ Sriwijaya University, Palembang, INDONESIA \\ ${ }^{2}$ Sriwijaya University, Palembang, INDONESIA \\ ${ }^{3}$ Sriwijaya University, Palembang, INDONESIA \\ ${ }^{4}$ Sriwijaya University, Palembang, INDONESIA
}

\begin{abstract}
The purpose of this study is to analyze the Effect of Business Environment on Start-up in Indonesia. This study specifically examines the effect of Gross Regional Domestic Product, Per Capita Expenditure, Unemployment Rate, Total Population, Computer Users and Individual Internet Users which are used as business environment indicators on the existence of startup businesses in 17 Indonesian Provinces during the 2013-2018 period using panel data regression analysis tools to prove that GRDP, Total Population, Computer Users and Internet Users have a positive and significant effect on the existence of start-up businesses in Indonesia. Meanwhile, expenditure per capita and the unemployment rate have a negative effect on the existence of start-up businesses in Indonesia.
\end{abstract}

Keywords: Business Environment, Start-up, Creation New Business

JEL Codes: 03, M2

How to cite: Igamo, Alghifari. M., Raneo, Agung. Putra., Khamisah, Nur. And Kurniawan, Arika (2020). Business Environment and Start-Up in Indonesia: Empirical Evidence from Province-level Data. Journal of Economic Development, Environment and people, 9(4). doi: https://doi.org/10.26458/iedep.v9i4.680

\section{Introduction}

The creation of a new business is the most attractive issue, especially in the entrepreneurship process to drive economic growth (Munemo, 2017). Empirical studies show that entrepreneurship and the establishment of new companies play a significant role in promoting economic growth, job creation, and increased productivity and competitiveness (Acs et al. 2012; Aparicio, Urbano, and Audretsch 2016; Thurik et al. 2008; Dnjankov et al 2002; Klapper et al 2006; Black and Strahan 2002). It is also emphasized by (Ayyagari et al 2011, Haltiwanger et al 2010) that the impact of start-ups contributes more to job creation than mature firms.

\footnotetext{
${ }^{1}$ Corresponding author. Tel/Mobile Phone: +62 81367111292 ; E-mail address: alghifari@unsri.ac.id
} 


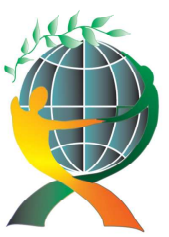

\author{
(online) $=$ ISSN $2285-3642$ \\ ISSN-L = $2285-3642$ \\ Journal of Economic Development, Environment and People \\ Volume 9, Issue 4, 2020
}

URL: http://jedep.spiruharet.ro

e-mail: office jedep@spiruharet.ro

Castano et al (2015) argue that entrepreneurship is one of the main drivers of growth and reduce the unemployment rate in certain countries due to the adverse effects of the recession.

Entrepreneurship and new business creation are gradually becoming engines of job creation and economic growth.

Weller and Singleton (2004) argue that better economic institutions and democracy seem to promote positive economic outcomes. In Roman et al's research (2018), the significant role of entrepreneurship also recognized by policymakers in various countries, who increase their efforts to improve the business environment through measures aimed at encouraging and supporting the creation of new companies and entrepreneurship by removing some constraints to start a company and do business. The results showed that macroeconomic and demographic variables were the most significant determinants, followed by the characteristics of individual entrepreneurs and business environments. Kozubivoka et al (2019) state the favorable business environment determined by politics, technology, economy, social are the influencing factors to start a business. A country's internal business environment is undoubtedly a significant factor that influences to start a new business and the business itself, primarily determined by political factors (including laws) and the economic conditions of each country. Good quality institutions and countries make investment opportunities more attractive by enforcing the rule of law, controlling corruption, maintaining political stability, and promoting other forms of good governance (Fan et al. 2009; Lederman et al. 2013).

Table 1. Ease of Doing Business Index For Lower Middle Income Country

In ASEAN Region 2018-2019

\begin{tabular}{|c|c|c|c|c|c|c|c|}
\hline & Indonesia & Vietnam & Philippines & Cambodia & Laos & Myanmar & Timor Leste \\
\hline Year & \multicolumn{7}{|c|}{ Ranking (Score) } \\
\hline & & & & & & & \\
\hline 2018 & $72(66.47)$ & 68 & $113(58.74)$ & 135 & $141(53.01)$ & 171 & $178(40.62)$ \\
& & $(67.93)$ & & $(54.47)$ & & $(44.21)$ & \\
\hline 2019 & $73(67.96)$ & 69 & $124(57.68)$ & 138 & $154(51.26)$ & 171 & $178(41.60)$ \\
& & $(68.36)$ & & $(54.80)$ & & $(44.72)$ & \\
\end{tabular}

Source: doingbusiness.org

Based on data released by the World Bank, there can be a progress of ease of doing business index in several ASEAN countries that fall into the category of a lower-middle-income country. The calculation of the index consists of several aspects including starting a business (procedures, time, cost, and minimum capital to start a new business, access to credit, protection investors). Statistical data shows Indonesia has decreased its ranking, in 2018 Indonesia was ranked 72nd and dropped to one level in the next year despite increasing the index score to 67.96 in 2019. Compared to other lower-middle-income countries, Vietnam has better value and position related to doing business. Ease of Doing Business Index can be a reference to assess a country's business environment, but there are some lags because it has not included important elements such as 


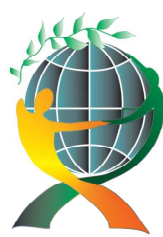

\author{
(online) = ISSN $2285-3642$ \\ ISSN-L = $2285-3642$ \\ Journal of Economic Development, Environment and People \\ Volume 9, Issue 4, 2020
}

URL: http://jedep.spiruharet.ro

e-mail: office jedep@spiruharet.ro

macroeconomic stability, labor force quality, and market size. Therefore this study tries to fill the gap to identify a good business environment at the provincial level in Indonesia.

Table 2. Indonesian Mapping Start-up in 2018

\begin{tabular}{|l|c|c|}
\hline \multicolumn{1}{|c|}{ Region } & Number of Start-up & Percentage \\
\hline Jabodetabek & 522 & $52.62 \%$ \\
\hline Central Java & 30 & $3.02 \%$ \\
\hline Yogyakarta & 54 & $5.44 \%$ \\
\hline West Java & 44 & $4.44 \%$ \\
\hline East Java & 113 & $11.39 \%$ \\
\hline Bali \& NTB & 32 & $3.23 \%$ \\
\hline Kalimantan & 24 & $2.42 \%$ \\
\hline Sulawesi Total & 34 & $3.43 \%$ \\
\hline Sumatera Source: Mapping \& & 115 & $11.53 \%$ \\
\hline Unknown Domicile & 24 & $2.42 \%$ \\
\hline \multicolumn{2}{|c|}{922} & $100 \%$ \\
\hline
\end{tabular}

Source: Mapping \& Database Start-up (BEKRAF)

One of the new business creation phenomena is the growth of a start-up. Statistical data shows the development of start-ups spread almost throughout Indonesia in 2018. Based on data released by the Creative Economy Agency (BEKRAF), the number of start-ups in Indonesia reached 922 as of 2018 . The start-ups are engaged in their respective fields such as 325 start-ups in E-Commerce, 53 start-ups in Fintech, 55 start-ups in the field of gaming, and the rest are in other fields. There is an alleged number of start-ups that continue to grow in Indonesia because of an excellent business environment.

\title{
2. Formulation of The Problem
}

How the business environment affects the development of Start-Ups in Indonesia during the observation period?

\section{Theoretical And Literature Review}

Entrepreneurship activity and the creation of new businesses can be influenced by various factors. Factors affecting business and entrepreneurship can vary by region and country. These factors can be divided into social, cultural, and economic factors. Socially, the structure and social development of a country are important factors, as well as culture. According to Bosma and Schutjens (2011), starting a new business depends on the level of economic development and the demographic, cultural, institutional, and technological characteristics of a country. Schumpeter (1934) this concept involves a sociological, economic, and institutional climate of society in which entrepreneurs conduct business activities. These factors include social values, training, 


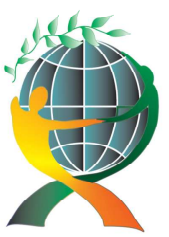

\author{
(online) $=$ ISSN $2285-3642$ \\ ISSN-L = $2285-3642$ \\ Journal of Economic Development, Environment and People \\ Volume 9, Issue 4, 2020
}

URL: http://jedep.spiruharet.ro

e-mail: office jedep@spiruharet.ro

economic freedom levels, and institutional quality. Therefore, the appropriate social climate can encourage and stimulate entrepreneurial activities, increase economic growth, and job creation. Regarding entrepreneurship, it should take into account the role of institutions from a variety of views. Because Baumol (1990), Boettke and Coyne (2003), and Sobel (2008) claim the institutional structure in society determines the type of entrepreneurship.

A country's economic performance also plays an important role, as greater economic activity creates positive economic expectations and improves the perception of opportunity, motivating individuals to engage in entrepreneurial activities. Therefore, any initiative that enhances the economic activity and helps build a stable macroeconomic environment stimulates entrepreneurship. Low-interest monetary policy and low tax rates can produce desirable outcomes such as increased economic activity and greater economic stability (Bourguignon \& Verdier, 2000; Galor \& Zeira, 1993).

The Business environment is a very complex indicator to describe. Verheul et. al (2002) explained that entrepreneurship can be influenced by the demand and supply sides. From the demand side, various factors that can affect the emergence of new businesses are economic conditions and technological developments, while factors from the supply side are influenced by growth rates, population structure, unemployment, and income levels.

Ron Kemp et al. (2006) stated that changes in the dynamics and growth of companies play an important role in increasing economic growth, especially start-up companies that grow relatively fast and contribute greatly to job creation. According to Salamzadeh and Kesim (2015) start-up companies are new companies that are struggling for existence, so the ability to know a good business environment is needed so that the company can develop.

Some previous studies linked the business environment to being influenced by the economic condition of a country. (Bosma and Schutjens 2011; Thurik, Wennekers, and Uhlaner 2002; Verheul et al. 2002; Wennekers et al. 2005) highlights that the dynamics of entrepreneurial levels (e.g., young or newborn entrepreneurs) depend on the level of economic development and the demographic, cultural, institutional, and technological characteristics of each country. Established new businesses and entrepreneurial activities significantly influenced by the economic and social environment, and supported by entrepreneurial finance, government policy, government entrepreneurship programs, entrepreneurial education, research and development transfers, commercial and legal infrastructure, infrastructure and internal market dynamics, internal regulatory market dynamics and entries, physical infrastructure, and cultural and social norms (Kelley, Singer, and Herrington 2016). Shane (2008) investigated the effects of variations in gross domestic product (GDP) and GDP growth per capita on entrepreneurial activity and showed that the impact of GDP variation differed, depending on the country's level of development.

Individual characteristics explain most of the differences in the decision to become an entrepreneur, followed by economic characteristics and local cultural values. Arenius and Minniti (2005) empirically analyzed the impact of several demographic and economic factors (age, gender, employment status, education, and household income) affecting a person's decision to become entrepreneurial and start a business. 


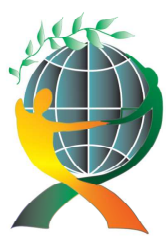

\author{
(online) = ISSN $2285-3642$ \\ ISSN-L = 2285 - 3642 \\ Journal of Economic Development, Environment and People \\ Volume 9, Issue 4, 2020
}

URL: http://jedep.spiruharet.ro

e-mail: office_jedep@spiruharet.ro

Grilo and Thurik (2004) show that business creation is influenced by demand and supply. Demand for entrepreneurship is determined by economic development, technological development, and globalization. At the same time, the supply side of entrepreneurship is defined by population characteristics (e.g., population growth, age structure, and population density), income level, income disparity, and unemployment.

(Arin et al. 2015) shows that the level of entrepreneurial activity and creation new business in a country is significantly influenced by three factors. Human capital (population size, quality of education, and unemployment), development rates (GDP per capita, technology development, and financial development), and institutions (taxes, inflation, administrative complexity, and globalization). In a general, entrepreneurship is significantly influenced by only four major macroeconomic variables: GDP per capita, unemployment, inflation, and taxation. According to Sternberg (2009), the factors deciding to set up a new company are represented by the national environment (e.g., cultural norms and values, infrastructure, capital, education, macroeconomic trends), regional environment (e.g., regional PDRB growth, regional job growth, regional policy, regional infrastructure), microenvironment (e.g., family, friends), and personal characteristics of potential entrepreneurs (e.g., entrepreneurial motivation, gender, age, willingness to take risks).

\title{
4. Methodology and Data
}

The object of this research is the influence of the business environment on start-ups in Indonesia. The business environment in this study consists of variables of Gross Regional Domestic Product, Per Capita Expenditure, unemployment rate, population growth rate, population using computers, and individual internet users. The discussion is limited to covering 17 provinces in Indonesia. The data used in this study are from 2013-2018. There are three fundamental approaches used in estimating the regression model with panel data, namely: a) Pooled Least Square (Common Effect) Model. b). Fixed Effect Approach Model, and c). Random Effect Approach Model. The panel data regression equation in this model is:

Where :

$$
\text { Startup }_{i t}=\alpha+\beta_{1} P R_{i t}+\beta_{2} P P_{i t}+\beta_{3} T P_{i t}+\beta_{4} J P_{i t}+\beta_{5} P_{i t}+\beta_{6} I P I_{i t}+e_{i t}
$$

Startup $_{\text {it }}=$ The number of startup companies based on the year of existence

$\mathrm{PDRB}_{\text {it }} \quad=$ Gross Domestic Regional Products

$\mathrm{PP}_{\text {it }} \quad=$ Per Capita Expenditure

$\mathrm{TP}_{\mathrm{it}} \quad=$ Unemployment Rate (Rupiah)

$\mathrm{JP}_{\text {it }} \quad=$ Population

$\mathrm{PK}_{\text {it }} \quad=$ Percentage of Computer Users

$\mathrm{IPI}_{\text {it }} \quad=$ Percentage of Internet Users

$\propto \quad=$ A constant

$\beta \quad=$ Regression coefficient

$\mathrm{e}_{\mathrm{it}} \quad=$ error term 


\author{
(online) $=$ ISSN $2285-3642$ \\ ISSN-L = $2285-3642$ \\ Journal of Economic Development, Environment and People \\ Volume 9, Issue 4, 2020 \\ URL: http://jedep.spiruharet.ro \\ e-mail: office jedep@spiruharet.ro
}

\title{
Hypotesis
}

Gross Regional Domestic Product, Per Capita Expenditure, unemployment rate, population growth rate, population using computers, and individual internet users have a significant effect on business start-ups.

\section{Empirical Result}

\subsection{Model Estimation Output}

Panel data regression uses three models, namely the Common Effect Model, Fixed Effect Model, and Random Effect Model, several tests to choose which model is best in predicting the regression model from the research conducted, namely the Lagrange Multiplier Test, Chow Test and Hausman Test.

Table 3. Model Estimation Output

\begin{tabular}{crrrrrr}
\hline \multirow{2}{*}{ Variabel } & \multicolumn{2}{c}{ Common } & \multicolumn{2}{c}{ Fixed } & \multicolumn{2}{c}{ Random } \\
\cline { 2 - 7 } & Koefisien & Prob. & Koefisien & Prob. & Koefisien & Prob. \\
\hline C & 55.67021 & 0.0576 & 288.609 & 0.1542 & -630.6 & 0.3814 \\
LNPDRB? & 0.264821 & 0.0297 & 1.2218 & 0.1016 & -2.2784 & 0.4364 \\
LNPP? & -10.53859 & 0.0026 & -43.062 & 0.0019 & 49.3234 & 0.5348 \\
TP? & -0.053364 & 0.7937 & -0.5561 & 0.0669 & 0.90143 & 0.5965 \\
LNJP? & 3.957667 & 0.0000 & 11.1843 & 0.4759 & 18.5745 & 0.0014 \\
PK? & 0.209139 & 0.0016 & 0.19175 & 0.1477 & 2.71296 & 0.0032 \\
IPI? & 0.065941 & 0.0010 & 0.15095 & 0.0226 & -0.3615 & 0.1148 \\
\hline
\end{tabular}

Source: Processed With Eviews

Based on the estimation results shown in Table 3, it shows that the best model with statistical estimation is the Common Effect Model (CEM) which can be seen that almost all independent variables can be declared statistically significant including the LNPDRB, LNPP, LNJP, PK and IPI variables. Meanwhile, the TP variable is not statistically significant. Meanwhile, for the Fixed Effect Model (FEM) and the Random Effect Model (REM), almost all independent variables are declared to have no significant effect on start-up businesses.

Based on the results of the Common Effect Model (CEM) estimation, it can be interpreted as follows by the following equation model:

\section{$S U=55,67+0.2648$ LNPDRB -10.538 LNPP $-0.053 \mathrm{TP}+3.3957 \mathrm{JP}+0.209 \mathrm{PK}+0.0696 \mathrm{IPI}$}

The results show that the GRDP (Gross Regional Domestic Product) will encourage the existence of a business start-up. This condition is proven statistically which shows a positive influence in Indonesia. The pattern of national income as measured by the value of GRDP in Indonesia which tends to increase in Indonesia 


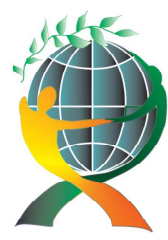

\author{
(online) = ISSN $2285-3642$ \\ ISSN-L = $2285-3642$ \\ Journal of Economic Development, Environment and People \\ Volume 9, Issue 4, 2020
}

URL: http://jedep.spiruharet.ro

e-mail: office jedep@spiruharet.ro

during the 2013-2018 period will encourage an increase in business start-ups. Empirically, the conditions that explain the economic performance of a country also have an important role, because greater economic activity creates positive economic expectations and increases perceptions of opportunities, motivating individuals to engage in entrepreneurial activities. Hence, any initiative that increases economic activity and helps build a stable macroeconomic environment stimulates entrepreneurship.

The results of this study are in line with several studies that prove that a country's economic performance has a positive and significant effect on startup business (Westlund et al., 2013). This finding illustrates the relationship between startups and economic development (local / regional) providing a positive boost to the existence of a startup business. In line with this, this finding is supported by (Okrah et al., 2018) who found that the determinant of start-up growth is the condition of national income as measured by the country's GDP.

The empirical evidence shows that per capita expenditure has a negative and significant effect on the existence of start-up businesses. The condition explains that an increase in per capita expenditure will have a negative impact on the start-up position in Indonesia. The most likely reason for explaining this condition is because the proxies used in measuring expenditure per capita are generally categorized as a whole, both urban and rural. Besides, these measurements can be assessed as the tendency of public expenditure patterns in Indonesia to tend to be dynamic and prioritize primary needs, so that the phenomenon of increasing spending per capita has not been able to encourage an increase in startup presence due to the different characteristics of business startup companies based on their fields and activities in each region in Indonesia.

Expenditure per capita can be explained based on consumption theory considering that consumption patterns in Indonesia still fulfill primary needs that tend not to utilize technology, especially electronic or digital purchases. This pattern has an impact on the decline in a startup business in terms of per capita expenditure, which tends to meet primary needs as a whole, which is often not available digitally and has accessibility to rural and urban communities.

This study is in line with Bostman (2013) who found that public consumption patterns, both monetary and non-monetary, which tend not to use technology, will have an impact on the business cycle, especially digital entrepreneurship. This stigma can allow a decline in the growth of startup businesses. In contrast with this, Schaltegger \& Wagner, (2011) Start-up business is able to challenge established companies by providing obstacles for companies that still use conventional methods including production, products, market structures as well as providing changes in existing consumption patterns, and replacing them with environmental and social superior products and services. This means that by increasing per capita expenditure, consumption patterns will change before being conventional with start-up interactions changing to lead to digitization, thus this interaction will have a positive impact on the existence of Startups.

The results showed that the unemployment rate has a negative effect, meaning that the higher the unemployment rate threatens the existence of start-up businesses in Indonesia. In addition, the issue of unemployment is related to self-employers, but this condition is not fundamental in the case in Indonesia which is related to qualifications to become entrepreneurs, especially in the start-up business sector (Caliendo et al., 2007). Berglann et al., (2011) stated that unemployed job seekers have a higher likelihood of starting a new business venture because individual unemployment encourages entrepreneurship. The need for start-ups is more likely the result of start-ups being unemployed due to the loss of job alternatives (Caliendo et al., 2015). 


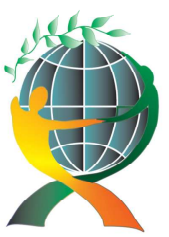

\author{
(online) $=$ ISSN $2285-3642$ \\ ISSN-L = $2285-3642$ \\ Journal of Economic Development, Environment and People \\ Volume 9, Issue 4, 2020
}

URL: http://jedep.spiruharet.ro

e-mail: office jedep@spiruharet.ro

This is also related to unemployment triggering creativity, in fact, individuals can develop entrepreneurship because the opportunity cost of establishing a new business is relatively low. In general, this condition can be concluded that with the case of Indonesia, which is generally the phenomenon of business start-ups which is still low, it can be seen from the existence of start-up businesses that are still small, although in previous studies many have suggested unemployment provides a driving factor in creating entrepreneurship, in Indonesia it needs to be known This trigger has not yet been created in the manpower conditions that still have the capacity in this field, especially the start-up market in Indonesia which requires high capital.

This study found that an increasing population had a positive impact on the existence of start-up businesses in Indonesia. The demographic structure in Indonesia, which is still categorized as a young population, has an impact on different technological patterns, with a population that has high productivity, especially at a young age, will provide opportunities for creating more businesses, this can be proven that many of the startup businesses in Indonesia are controlled by younger generations who are more tech-literate and read the opportunities of the future.

This is in line with the study (Liang et al., 2014) which found that the structure of the elderly population will overthrow entrepreneurship. Consistent with this, most digital entrepreneurs are millennials or younger, born after 1982. This does not mean that parents cannot encourage digital innovation as much as they can. However, this generation is needed to face the pace of contemporary digital transformation (Rossi, 2019).

The results show that the increasing number of computer users will encourage an increase in the presence of startup businesses in Indonesia, the higher pattern of technology use along with digital transformation has a positive impact on the existence of start-up businesses in Indonesia. This condition relates to opportunities in the digital industry, with the increasing number of users of technology devices (smartphones, computers, etc.). the fact is that Indonesia is getting used to the use of technology, and it seems that the younger generation likes to use their smart devices.

The very rapid development of technology has a positive impact, especially on the existence of start-ups, this condition is related to the unlimited reach of creativity in the creation of new businesses, the use of technology is currently being used to support creativity that encourages entrepreneurs (Hughes, 2020). Consistent with Maemunah (2017) who found that information and communication technology (ICT) and business strategy had a positive and significant effect on business performance in small and medium enterprises. Given that information and communication technology is not ready for use, small and medium enterprises need to recognize the workings offered by internet applications so that they can be explored according to the desired business strategy and process. The business strategy of small and medium enterprises in reaching a wider market and can reduce costs compared to traditional sales and buying techniques.

The results show that individual internet users have a positive and significant effect on start-up businesses, this proves that increasing internet users will increase the existence of startup businesses, this condition is related to the rapid development of technology and digital transformation that encourages the existence of Start-Up businesses. The pattern of digital transformation that occurs in Indonesia encourages the number of businesses that use the internet's special technology which creates a wide and unlimited reach, this condition is considered as an opportunity to create new businesses. 


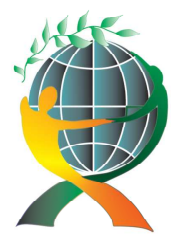

\author{
(online) = ISSN $2285-3642$ \\ ISSN-L = $2285-3642$ \\ Journal of Economic Development, Environment and People \\ Volume 9, Issue 4, 2020
}

URL: http://jedep.spiruharet.ro

e-mail: office_jedep@spiruharet.ro

line with this, businesses that can fully adopt loT will be able to increase their profits by increasing their overall productivity, lowering operating costs or entering new markets so that many entrepreneurs consider the internet an opportunity in creating broad-term businesses at low cost, this condition will increase the existence of start-up businesses (Phaneuf, 2020). Consistency with this, Leber (2012) recommends that the internet can change the entire industry, or at least substantially, this paradigm which in turn will help companies to develop new products and processes faster, increase productivity, and increase customer satisfaction.

\title{
6. Conclusion
}

This study specifically examines the effect of GRDP (Gross Regional Domestic Product), Per Capita Expenditure, Unemployment Rate, Total Population, Computer Users and Individual Internet Users which are used as business environment indicators on the existence of startup businesses in 17 Indonesian Provinces during the 2013-2018 period using panel data regression analysis tools to prove that GRDP, Total Population, Computer Users and Internet Users have a positive and significant effect on the existence of start-up businesses in Indonesia. Meanwhile, per capita expenditure and unemployment rate have a negative effect on the existence of start-up businesses in Indonesia. The findings in this study prove that technology, information and communication from the point of view of computer and internet users have a positive impact on the existence of business in Indonesia, digital business players must take advantage of this as a business opportunity in the future by adopting various technologies, especially the Internet of Things (IoT) which can increase profitability and overall productivity while lowering costs. Concerning loT, the government is expected to provide facilities related to this by improving IT infrastructure throughout Indonesia. The limitations of this research cannot describe broadly the determinants of the start-up business existence because it only uses the scope of 17 Provinces with the 2013-2018 period, several variables that are expected to become further studies related to digital business development, namely venture capital and the characteristics of digital entrepreneurship, especially the young generation in Indonesia.

\section{References}

Acs, Z. J., D. B. Audretsch, P. Braunerhjelm, and B. Carlsson. 2012. Growth and entrepreneurship. Small Business Economics 39 (2):289-300. doi:10.1007/s11187-010-9307-2

Aparicio, S., D. Urbano, and D. Audretsch. 2016. Institutional factors, opportunity entrepreneurship and economic growth: Panel data evidence. Technological Forecasting and Social Change 102:45-61. doi:10.1016/j.techfore.2015.04.006.

Arenius, P., and M. Minniti. (2005). Perceptual variables and nascent entrepreneurship. Small Business Economics 24 (3):233-47. doi:10.1007/s11187-005-1984-x.

Arin, K. P., V. Z. Huang, M. Minniti, A. M. Nandialath, and O. F. M. Reich. (2015). Revisiting the determinants of entrepreneurship: A bayesian approach. Journal of Management 41 (2):607-31. doi:10.1177/0149206314558488.

Ayyagari, M., Demirguc-Kunt, A., \& Vojislav, M. (2011). Small vs. young fifirms across the world: contribution to employment, job creation, and growth. In Policy research working paper series 5631. World Bank. 


\author{
(online) $=$ ISSN $2285-3642$ \\ ISSN-L = $2285-3642$ \\ Journal of Economic Development, Environment and People \\ Volume 9, Issue 4, 2020 \\ URL: http://jedep.spiruharet.ro \\ e-mail: office jedep@spiruharet.ro
}

Baumol, W. (1990). Entrepreneurship: Productive, unproductive, and destructive. The Journal of Political Economy, 98(5), 893-921

Bourguignon, F., \& Verdier, T. (2000). Oligarchy, democracy, inequality, and growth. Journal of Development Economics, $62,285-313$.

Boettke, P., \& Coyne, C. (2003). Entrepreneurship and development: Cause or consequence? Advances in Austrian Economics, 6,67-88.

Berglann, H., Moen, E. R., Røed, K., \& Skogstrøm, J. F. (2011). Entrepreneurship: Origins and returns. Labour Economics, 18(2), 180-193. https://doi.org/https://doi.org/10.1016/j.labeco.2010.10.002

Black, Sandra E. and Strahan, Philip E., Entrepreneurship and Bank Credit Availability. Journal of Finance, Vol. 57, pp. 28072833

Bosma, N., and V. Schutjens. (2011). Understanding regional variation in entrepreneurial activity and entrepreneurial attitude in Europe. The Annals of Regional Science 47 (3):711-42. doi:10.1007/s00168-010-0375-7.

Caliendo, M., Hogenacker, J., Künn, S., \& Wießner, F. (2015). Subsidized start-ups out of unemployment: a comparison to regular business start-ups. Small Business Economics, 45. https://doi.org/10.1007/s11187-015-9646-0

Caliendo, M., Kritikos, A. S., Caliendo, M., \& Kritikos, A. S. (2007). Start-Ups by the Unemployed : Characteristics, Survival and Direct Employment Effects. 3220.

Castano, M., Mendez, M., \& Galinda, M. (2015). The effect of social, cultural, and economic factors on entrepreneurship. Journal of Business Research. http://dx.doi.org/10.1016/j.jbusres.2015.01.040

Djankov, S., La Porta, R., Lopez-De-Silanes, F., \& Shleifer, A. (2002). The regulation of entry. Quarterly Journal of Economics, CXVII, 1, 1-37.

Galor, O., \& Zeira, J. (1993). Income distribution and macroeconomics. Review of Economic Studies, 60(1), 35-52

Grilo, I., and R. Thurik. (2004). Determinants of entrepreneurship in Europe. ERIM Report Series Reference no . ERS-2004106ORG.

Fan, J., Morck, R., Xu, L., \& Yeung, B. (2009). Institutions and foreign direct investment: China versus the rest of the world. World Development, 37(4), 852-865.

Haltiwanger, J., Jarmin, R., \& Miranda, J. (2010). Who create jobs? Small vs. large vs. young. US Census Bureau, Center for Economic Studies. CES Research Paper 10-7. 


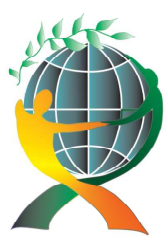

\author{
(online) = ISSN $2285-3642$ \\ ISSN-L = $2285-3642$ \\ Journal of Economic Development, Environment and People \\ Volume 9, Issue 4, 2020
}

URL: http://jedep.spiruharet.ro

e-mail: office jedep@spiruharet.ro

Hughes, M. (2020). Digital Entrepreneurship Impact on Business and Society. In Future of Business and Finance. Springer.

Klapper, L., Laeven, L., \& Rajan, R. (2006). Entry regulation as a barrier to entrepreneurship. Journal of Financial Economics, $82(3), 591-629$.

Kozubikova, L., Kotaskova, A., Dvorsky, J., \& Kljucnikov, A. (2019). The impact of political factors' perception on suitability of international business environment: The case of startups. Economics and Sociology, 12(1), 61-79. doi:10.14254/2071-789X.2019/12-1/3

Maemunah, S. (2017). The Effect Of Information And Communication Technology ( Ict ) And Business Strategy On Business Performance In Small And Medium Businesses. Business and Entrepreneurial Review, 17(1), 53-66.

Lederman, D., Mengistae, T., \& Xu, L. (2013). Microeconomic consequences and macroeconomic causes of foreign direct investment in Southern African economies. Applied Economics, 45(25), 3637-3649.

Leber, J. (2012). General Electric Pitches an Industrial Internet. MIT Technology Review.

Liang, J., Lazear, E. P., \& Liang, J. (2014). Demographics and Entrepreneurship.

Munemo, J. (2014). Business start-up regulations and the complementarity between foreign and domestic investment. Review of World Economics (Weltwirtschaftliches Archiv), Springer; Institut für Weltwirtschaft (Kiel Institute for the World Economy), vol. 150(4), pages 745-761, November. doi: 10.1007/s10290-014-0189-2

Okrah, J., Nepp, A., \& Agbozo, E. (2018). Exploring the factors of startup success and growth. The Business and Review, 9(3),

9-10. https://www.researchgate.net/publication/336642098 Exploring the factors of startup success and growth\%0A http://www.abrmr.com/myfile/conference proceedings/Con Pro 89747/2018icbedcp36.pdf

Phaneuf, A. (2020). Top loT business opportunities, benefits, and uses in 2020. https://www.businessinsider.com/iotbusiness-opportunities models?international=true\&r=US\&IR=T.

Roman, A., Bilan, I., \& Ciumaș, C. (2018) What Drives the Creation of New Businesses? A Panel-Data Analysis for EU Countries, Emerging Markets Finance and Trade, 54:3, 508-536, DOI: 10.1080/1540496X.2017.1412304

Ron Kemp \& Petra Gibcus \& P.M. de Jong-'t Hart, 2006. Determinants of Growth of Start-ups in the Netherlands. Scales Research Reports N200517. EIM Business and Policy Research

Rossi, R. (2019). Understanding millennials' and technology's role in the workforce, part one. Forbes.https://www.forbes.com/sites/forbesbusinessdevelopmentcouncil//07/03/understandingmillennials-andtechnologys-role-in-the-workforce-part-one/\#318e5e820344.

Salamzadeh, A., \& Kesim, A.K. (2015). Startup Companies: Life Cycles and Challenges. Conference Paper. doi:10.13140/RG.2.1.3624.8167 


\author{
(online) $=$ ISSN $2285-3642$ \\ ISSN-L = 2285 - 3642 \\ Journal of Economic Development, Environment and People \\ Volume 9, Issue 4, 2020 \\ URL: http://jedep.spiruharet.ro \\ e-mail: office jedep@spiruharet.ro
}

Schumpeter, J.A. (1934). The theory of economic development. Cambridge: Harvard University Press.

Sobel, R. (2008). Testing Baumol: Institutional quality and the productivity of entrepreneurship. Journal of Business Venturing, 23,641-665.

Sternberg, R. (2009). Regional dimensions of entrepreneurship. Foundations and Trends in Entrepreneurship 5 (4):211340. doi:10.1561/0300000024.

Schaltegger, S., \& Wagner, M. (2011). Sustainable Entrepreneurship and Sustainability Innovation: Categories and Interactions. 237(July 2010), 222-237.

Thurik, A. R., M. A. Carree, A. van Stel, and D. B. Audretsch. 2008. Does self-employment reduce unemployment? Journal of Business Venturing 23 (6):673-86. doi:10.1016/j.jbusvent.2008.01.007.

Verheul, I., S. Wennekers, D. Audretsch, and R. Thurik. (2002). An eclectic theory of entrepreneurship: Policies, institutions and culture. In Entrepreneurship: Determinants and policy in a European-US comparison. Boston and Dordrecht: Kluwer Academic Publishers.

Weller, C. E., and L. Singleton. (2004). "Political Freedom, External Liberalization and Financial Stability." International Review of Applied Economics 18 (1): 43-61.

Wennekers, S., A. van Stel, R. Thurik, and P. Reynolds. (2005). Nascent entrepreneurship and the level of economic development. Small Business Economics 24 (3):293-309. doi:10.1007/s11187-005-1994-8.

Westlund, H., Olsson, A. R., \& Larsson, J. P. (2013). Startups and their effeets on loeal development: The case of Sweden. Entrepreneurial Knowledge Technology and the Transformation of Regions, 251, 51-67. https://doi.org/10.4324/9780203486634

Website Bank Indonesia. www.bi.go.id

Website BEKRAF https://www.bekraf.go.id/pustaka/page/mapping-database-startup-indonesia-2018

Website Doing Business. https://www.doingbusiness.org/en/rankings 